\title{
Phytochemical Screening and Antibacterial Activities of Senggani (Melastoma malabathricum L.) Ethanolic Extract Leaves
}

\section{(Skrining Fitokimia dan Aktivitas Antibakteri dari Ekstrak Daun Senggani (Melastoma malabathricum L.))}

\author{
Retno Widowati ${ }^{*}$, Sri Handayani ${ }^{2}$, Ahmad Ridho Al Fikri ${ }^{2}$
}

(Diterima September 2021/Disetujui Oktober 2021)

\begin{abstract}
The aim of the current research was to perform phytochemical screening and to know the pathogenic antibacterial activities of senggani leaves extract. Phytochemical screening was done by testing eight active compounds. Antibacterial activities testing was done by using well diffusion method at concentration level of $25 \%, 50 \%, 75 \%, 100 \%$. Positive control was amoxicillin, while the negative control was aquadest. Meanwhile, pathogenic bacteria were Escherichia coli, Shigella dysenteriae, Staphylococcus aureus, and Pseudomonas aeruginosa. Research design applied was complete random design, in which the data collected were analyzed using one-way ANOVA, continued by post-hoc test through Tukey method to know which concentration provide the most significant difference. Research results showed that ethanolic extract of senggani leaves has eight active compounds, those are phenolics, alkaloids, flavonoids, tannins, triterpenoids, glycosides, steroids, and saponins. This further proved that the ethanolic extract of senggani leaves have antibacterial activity and are able to inhibit the growth of all bacteria tested. The best ability shown to inhibit $E$. coli bacteria was at concentration of $100 \%, S h$. dysenteriae and $P$. aeruginosa started at the concentration of $75 \%$, and $S$. aureus started at the concentration of $50 \%$.
\end{abstract}

Keywords: active compounds, bacteria growth, inhibition, well diffusion

\section{ABSTRAK}

Penelitian ini bertujuan untuk skrining fitokimia dan mengetahui aktivitas antibakteri patogen dari ekstrak daun senggani. Skrining fitokimia dilakukan dengan menguji delapan senyawa aktif. Uji aktivitas antibakteri menggunakan metode difusi sumuran dengan taraf konsentrasi $25 \%, 50 \%, 75 \%, 100 \%$. Kontrol positif yang digunakan adalah amoxicillin, dan akuades sebagai kontrol negatif. Bakteri patogen yang digunakan adalah Escherichia coli, Salmonella dysenteriae, Staphylococcus aureus, dan Pseudomonas aeruginosa. Rancangan yang digunakan dalam penelitian ini adalah rancangan acak lengkap. Analisis data menggunakan one-way ANOVA, dilanjutkan dengan uji post-hoc metode Tukey untuk mengetahui konsentrasi yang memberikan perbedaan paling bermakna. Hasil penelitian menunjukkan bahwa ekstrak etanol daun senggani memiliki delapan zat aktif yaitu senyawa fenolik, alkaloid, flavonoid, tanin, triterpenoid, glikosida, steroid, dan saponin. Penelitian ini menunjukan bahwa ekstrak etanol daun senggani mampu menghambat pertumbuhan semua bakteri uji. Kemampuan terbaik ekstrak etanol daun senggani menghambat bakteri E. coli pada konsentrasi $100 \%$, Sh. dysenteriae dan P. aeruginosa mulai konsentrasi $75 \%$, S. aureus mulai konsentrasi $50 \%$.

Kata kunci: daya hambat, difusi sumuran, inhibisi, senyawa aktif

\section{INTRODUCTION}

Indonesian government recognized the utilization of various plants as herbs for public health. Therefore, the Ministry of Health of the Republic of Indonesia has issued several regulations concerning the use or utilization of plants as traditional medicines. This is integrated with the efforts made by the Indonesian

${ }^{1}$ Department of Magister Biology, Graduate School, Universitas Nasional, Jalan Harsono RM No. 1, Ragunan, South Jakarta, 12550

2 Department of Biology, Faculty of Biology, Universitas Nasional, Jalan Sawo Manila No 61, Pejaten, Pasar Minggu, South Jakarta 12520

* Correspondence author:

Email: retno.widowati@civitas.unas.ac.id government to utilize its biodiversity resources. However, many plants which were used as traditional medicine are still based on hereditary habits which were not provided by scientific data yet.

One of the plants widely used as a traditional medicine to treat various diseases is Senggani or Senduduk or Harendong or Melastoma malabathricum L. (Melastomataceae). Senggani as etnomedicinal that is popular in Bangladesh (Rahmatullah et al. 2009); India (Ringmichon et al. 2010) and Malaysia (Joffry et al. 2012; Samad et al. 2018); Thailand (Tangjitman et al. 2015) as well as Brunei Darussalam (Taha et al. 2021). In Indonesia, senggani is also used for etnomedicinal by Sundanese people (Roosita et al. 2008); Dayak people (Apridamayanti \& Kurniawan 2018); Batak people (Silalahi et al. 2015); Talang 
Mamak community in Bukit Tigapuluh Jambi (Setyowati, 2006) and Batin ethnic society in Tabir District Merangin Regency Jambi (Jalius \& Muswita 2013).

Several parts of a plant, such as the roots, stems, leaves, flowers, and the fruit of Senggani, are reported to have pharmacological activities, such as antivirus, antibacterial, anti-parasites, cytotoxicity, antioxidants, anticoagulants, Platelet Activating Factor (PAF) inhibition, antiulcer, anti-inflammatory, wound healing, antipyretic activities, antinociceptive, antivenom, and antidiarrheal, at different dosages/concentrations (Joffry et al. 2012; Silalahi 2020). Moreover, it also potentially has the source of antioxidant reported by (Susanti et al. 2007; Sari et al. 2018).

These functions of sengani leaves are basically for the prevention and treatment of diseases caused by infections of bacterials. To complete the data about $M$. malabathricum as a medicinal plant from Indonesia that potentially becomes medicine to cure a disease caused by the infection of pathogenic bacteria, this study was conducted to screen phytochemical active compounds and antibacterial activities of the ethanolic extract of senggani leaves against four pathogenic bacteria, those are Escherichia coli, Shigella dysenteriae, Staphylococcus aureus, and Pseudomonas aeruginosa.

\section{MATERIAL AND METHODS}

\section{Sample, Extraction and Phytochemical Screening}

The senggani leaves used for the study were collected from Candika Village, Rimbo Tengah District, Muara Bungo Regency, Jambi Province. The senggani leaves extract ethanol $70 \%$ was made by using maceration method (Sembiring et al. 2018). Rotary evaporator was using for concentrated the filtrate. Qualitative screening was done on the phytochemical content of senggani leaves ethanolic extract consisted of eight phytochemical tests, those are phenolics, flavonoids, alkaloids, tannins, triterpenoids, glycosides, saponins and steroids. Phytochemical screening was done based on Harbone (1987). The process of making ethanolic extract and screening for phytochemical content of senggani leaves was carried out at the Research Center for Spices and Medicinal Plants, Bogor, West Java.

\section{Antibacterial Activities}

The bacterial in the current research were $E$. coli (ATCC 8739), Sh. dysenteriae (UnasCC 310), S. aureus (ATCC 6539), and $P$. aeruginosa (ATCC 9027) which were cultured on 24-hour Muller Hinton agar at room temperature. The bacterial suspension was prepared using a physiological solution of $\mathrm{NaCl}$ which was adjusted to the McFarland Standard 0,5. The method used was diffusion well with a well width of 6 $\mathrm{mm}$ on Muller Hinton agar in petri dish.
Amoxicillin $10 \mu \mathrm{g}$ was used for the positive control, while sterile distilled water was used for the negative control. Senggani leaves ethanolic extract used were at the concentration levels of $25 \%, 50 \%, 75 \%, 100 \%$. Approximately $50 \mu \mathrm{L}$ of senggani leaves ethanolic extract was put into a well in petri dish containing Muller Hinton agar medium on which the bacterial had been spreaded using the spread plate method (Dhuha 2016). Furthermore, the placement of bacterial suspension and control was done using random technique. The plates with the bacteria were incubated for 24 hours at $37^{\circ} \mathrm{C}$. The antibacterial activities was measured by the zone of inhibition in the form of a clear area formed around the well. The clear area formed around the well was observed and measured using a caliper. The antibacterial activites of senggani leaves ethanolic extract against the bacterial were carried out at the Microbiology and Genetics Laboratory of Universitas Nasional.

\section{Research Design}

The current research applied a completely randomized design (CRD-F) using two factors of (T1) four types of the bacterial and (T2) the senggani leaves ethanolic extract concentration which consisted of four concentration levels, those are 25\%, 50\%, 75\%, 100\%, one positive antibiotic control (amoxicillin) and one negative control (aquadest). Each treatment was repeated three times.

\section{Data Analysis}

The data obtained were analyzed using IBM SPSS Statistics 23.0. Concentration variation was considered as the independent variable, while the zone of inhibition of each bacteria was considered as the dependent variable. The resulting data were analyzed using oneway ANOVA and then continued by using a post-hoc test of Tukey method aiming to determine senggani leaves ethanolic extract concentration which gave the most significant difference.

\section{RESULTS AND DISCUSSIONS}

\section{Phytochemical}

The qualitative phytochemical screening results of senggani leaves ethanolic extract are shown in the following Table 1. In this research, senggani leaves

Table 1 Phytochemical screening results of senggani leaves ethanolic extract

\begin{tabular}{clc}
\hline No & Active compound & Results \\
\hline 1 & Phenolics & + \\
2 & Alkaloids & + \\
3 & Flavonoids & + \\
4 & Tannins & + \\
5 & Triterpenoids & + \\
6 & Glycosides & + \\
7 & Steroids & + \\
8 & Saponins & + \\
\hline
\end{tabular}


ethanolic extract contained eight active substances in the form of phenolics, flavonoids, alkaloids, tannins, triterpenoids, glycosides, saponins and steroids. The phytochemical screening result in this study is more complete than those by Noviyanty \& Linda (2020) in the $96 \%$ ethanol extract of senggani fruits. From the six active compounds that were tested, senggani fruits have flavonoids and tannins. The phytochemical screening result of the water extract of $M$. malabathricum leaves was known to have flavonoids, triterpenes, saponins, steroids and tannins (Zakaria et al. 2006). The result of a study by Danlandi et al. (2015) for the methanolic extract of leaves, flowers, fruits, and stems showed that all parts contained tannins, steroids, phenols, and flavonoids. The result of a study by Sembiring et al. (2018) showed that $70 \%$ ethanol extract from the stems, leaves, flowers, and fruits had flavonoids, terpenoids, alkaloids, tannins and only leaves that contained saponins.

The active or secondary metabolite compounds in the plant were alkaloids, sterols, triterpenes, glycolsides, saponins, steroids, phenolics, tannins, and flavonoids had an antibacterial activity that can inhibit or kill pathogenic bacteria using the chemical, physical, and biological activities (Ncube et al. 2008). The antibacterial mechanism of alkaloids compounds are inhibiting nucleic acid synthesis (Rao \& Venkatachalam 2000), disturbing membrane integrity and activity on the cytoplasmic membrane (Alhanout et al. 2010; Salmi et al. 2008). Saponins inhibiting bacterial growth by lowering the surface tension, resulting in increased cell permeability and the release of intracellular compounds (Ngajow et al. 2013). Tannins inhibiting the growth of bacteria due work like a siderophore to chelate iron from the substrate and make iron unavailable to bacteria (Akiyama et al. 2001) Tannins also inhibiting DNA topoisomerase works (Nuria et al. 2009), and inhibiting perform of formation on cell wall polypeptides (Fahriya \& Shofi 2011).

Phenolics compounds are free radical eliminators and metal chelators, and cause inhibiting various bacterial physiological activities (Takó et al. 2020). Another mechanism of phenolic as antibacterials are denaturing cell proteins and inhibiting bacterial nucleic acid synthesis (Bachtiar et al. 2012). The antibacterial mechanisms of flavonoids are inhibition of microbial enzymes, inhibition of energy metabolism, inhibition of cytoplasmic membrane function, inhibition of porins in cell membranes, alteration of membrane permeability, inhibition of nucleic acid synthesis, inhibition of biofilm attachment and formation, and attenuation of pathogenicity (Miklasińska-Majdanik et al. 2018; Xie el al. 2015).

Triterpenoid compounds inhibiting bacterial growth through protein synthesis inhibition (Siregar et al. 2012) and disrupt the cytoplasmic membrane (de Leon et al. 2010). The antibacterial mechanisms of steroid compounds are inhibiting the cell membrane function and forming a complex compound of extracelluler protein. Steroid compounds cause damage of the cell membrane, follow and release the intracellular compound (Maesyaroh et al. 2017). Glycoside compounds have inhibition the bacterial growth by penetrating into the cell wall, damaging the components of the bacterial cell wall, inhibiting the cell membrane functions and bind extracellular proteins to form complex compounds. The complex compounds cause cell membranes damage, and follow and release the intracellular compounds (Sunawan et al. 2018; Supriatno \& Rini 2018).

The mechanism of phytochemical compounds playing a role in antibacterial activity. Phytochemical compounds are metal chelators and efflux pump inhibitors that will inhibit the bacteria growth using the mechanism of quorum sensing inhibitory by preventing the formation and destroying the biofilm formed by pathogenic bacteria. Besides, phytochemical compounds can disturb the regulation of quorum sensing and gene expression that is responsible for the biofilm formation and the virulence of pathogenic bacteria (Borges et al. 2016). Thus, phytochemical compounds naturally have a mode of distinctive multitarget.

\section{Antibacterial Activities}

The average of zone of inhibition of bacterial growth $E$. coli, Sh. dysenteriae, $S$. aureus, dan $P$. aeruginosa shown in Figure 1. The zone of inhibition is shown by the formation of a clear zone around the well indicating no bacteria growth is shown. This is caused by the toxicity of antibacterial activity from the ethanolic extract of senggani leaves that is bacteriocide, indicating that it can kill the test microorganisms to form the zone of inhibition (Sulistiyowati \& Siswati 2016). The potency of a clear zone to be formed can be compared to the CLSI (2016), if the zone of inhibition diameter is $\leq 14 \mathrm{~mm}$, the bacteria is considered resistant. If the zone of inhibition diameter is $15-19 \mathrm{~mm}$, the bacteria are considered intermediate, and if the zone of inhibition is $\geq 20 \mathrm{~mm}$, the bacteria are considered sensitive.

With such a result, it can be said that $E$. coli and $S h$. dysenteriae did not show sensitivity to the ethanolic extract of senggani leaves that had been given. $S$. aureus is sensitive to the ethanolic extract of senggani leaves at the following concentrations: $50 \%, 75 \%$, and $100 \%$ with a zone of inhibition diameter of $23.30 \mathrm{~mm}$, $23.60 \mathrm{~mm}$, and $24.50 \mathrm{~mm}$ consecutively. $P$. aeruginosa is sensitive to the ethanolic extract of senggani leaves with a concentration starting from $75 \%$ (Table 2 ).

In the positive control of $10 \mu \mathrm{g}$ amoxicillin, the zone of inhibition diameter with an average of $19 \mathrm{~mm}$ in $E$. coli can be formed, so it is considered intermediate. The other test bacteria are also sensitive to $10 \mu \mathrm{g}$ amoxicillin because they have an inhibition zone of more than $20 \mathrm{~mm}$. The average zone of inhibition diameter shown by $S h$. dysenteriae of $27.60 \mathrm{~mm}, S$. aureus of $47.30 \mathrm{~mm}$, and $P$. aeruginosa of $29.43 \mathrm{~mm}$. In the negative control of distilled water, the zone of inhibition is not formed because distilled water does not 


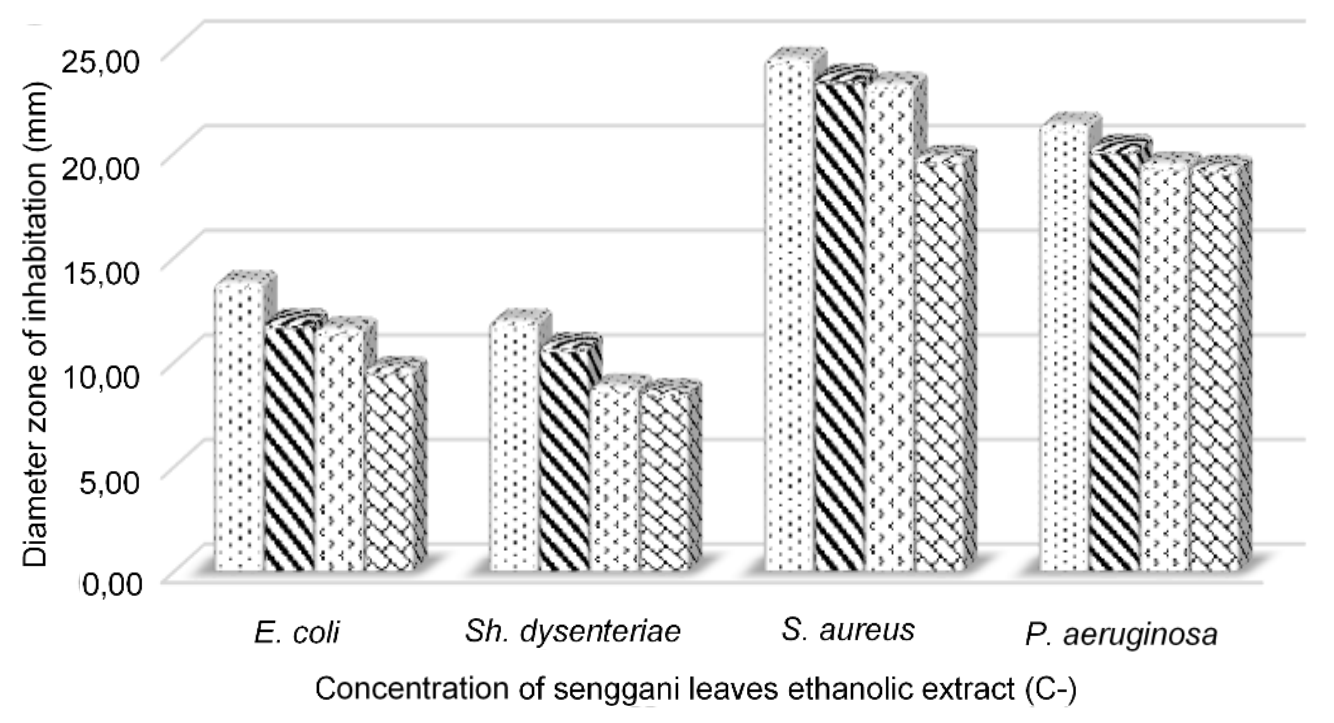

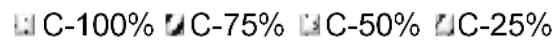

Figure 1 Average diameter zone of inhibition

Table 2 Post-hoc test results using Tukey method

\begin{tabular}{|c|c|c|c|c|}
\hline \multirow{2}{*}{ Senggani leaves ethanolic extract concentration } & \multicolumn{4}{|c|}{ Zone of inhibition diameter of bacterial growth $(\mathrm{mm})$} \\
\hline & E. coli & Sh. dysenteriae & S. aureus & P. aeruginosa \\
\hline $25 \%$ & $9.70^{\mathrm{a}}$ & $8.63^{\mathrm{a}}$ & $19.80^{\mathrm{a}}$ & $19.33^{a}$ \\
\hline $50 \%$ & $11.60^{\mathrm{b}}$ & $8.86^{\mathrm{a}}$ & $23.30^{\mathrm{b}}$ & $19.50^{\mathrm{a}}$ \\
\hline $75 \%$ & $11.96^{b}$ & $10.83^{b}$ & $23.66^{b}$ & $20.30^{\mathrm{ab}}$ \\
\hline $100 \%$ & $13.80^{c}$ & $11.96^{\mathrm{b}}$ & $24.50^{\mathrm{b}}$ & $21.36^{b}$ \\
\hline Control + & $19.03^{d}$ & $27.66^{c}$ & $47.30^{c}$ & $29.43^{c}$ \\
\hline Control - & $6.00^{\mathrm{e}}$ & $6.00^{\mathrm{e}}$ & $6.00^{\mathrm{e}}$ & $6.00^{\mathrm{e}}$ \\
\hline
\end{tabular}

Different letters behind the numbers indicate significant differences based on the post-hoc test conducted using Tukey method with $p<0.05$ for each type of bacteria, at each concentration, positive control, and negative control

contain antibacterial compounds. Thus, adding distilled water does not affect the concentration variation of the ethanolic extract of senggani leaves (Table 2).

The results of post-hoc test analysis using the Tukey method obtained the zone of inhibition diameter as an antibacterial form for each senggani leaves ethanolic extract concentration, positive control, and negative control on each type of test bacteria, are shown in Table 2. The data analysis results using oneway ANOVA test regarding the antibacterial activities of the ethanolic extract of senggani leaves obtained a significance value of $p<0.05$. This indicates that the ethanolic extract of senggani leaves has the antibacterial activities on $E$. coli, Sh. dysenteriae, $S$. aureus, and $P$. aeruginosa. The post-hoc test was further conducted using the Tukey method to determine the concentrations that had significant differences. Different results were obtained from the antibacterial testing of the senggani leaves ethanolic extract on the growth of the test bacteria at each concentration level, in which the greater the concentration, the greater the zone of inhibition. It indicates that ethanolic extract of senggani leaves at a concentration of $100 \%$ is the best concentration as an antibacterial $E$. coli. Ethanolic extract of senggani leaves at a concentration of $75 \%$ and $100 \%$ are the same activities ability as antibacterial Sh. dysenteriae, and the recommended concentration is $75 \%$ which is not significantly different from $100 \%$ concentration.

Ethanolic extract of senggani leaves at concentrations of $50 \%, 75 \%$ and $100 \%$ had same antibacterial ability against $S$. aureus, and the recommended concentration is $50 \%$ which is not significantly different from $75 \%$ and $100 \%$. The ethanolic extract of senggani leaves with a concentration of $75 \%$ and $100 \%$ had same antibacterial ability against $P$. aeruginosa, and the recommended concentration is $75 \%$ which is not significantly different from the concentration of $100 \%$.

The ethanolic extract of senggani leaves had antibacterial activites on all bacteria, both Gram positive (S. aureus) and Gram negative (Sh. dysenteriae, E. coli, $P$. aeruginosa). Antibacterial activeties in the ethanolic extract of senggani leaves are combination of various types of active substances contained. The results of the previous supporting research indicated that each of these active substances from the phytochemical screening had antibacterial abilities. Alkaloids have inhibition ability against both of bacteria Gram negative, and Gram positive including Sh. dysenteriae and E. coli (Karou et al. 2005) and S. aureus (Wang et al. 2013). Saponins have ability to inhibit the growth of $E$. coli isolated from hospitals (Arabski et al. 2012) and multidrugs resistant 
strains Gram-negative bacteria (Karou et al. 2005). Tannins have antibacterial activities to pathogenic bacteria Gram negative and Gram positive (Kurhekar 2016).

The antibacterial effect of phenolic compounds is very heterogeneous in both of bacteria Gram negative and Gram positive (Bouarab-Chibane et al. 2019). Flavonoids have antibacterial activities on bacteria Gram negative and Gram positive (Cushnie \& Lamb 2011). Triterpenoids showed antibacterial activities against E. coli and S. aureus (Angeh et al. 2007), and methicillin-resistant $S$. aureus (MRSA3) (Nzogong et al. 2018). Glycosides extracts indicated an inhibition effect on $S$. aureus strain ATCC23 and $P$. aeruginosa strain ATCC53, but had no effect on E. coli strain ATCC22 (Soulef et al. 2014).

Therefore, the discussion explained above revealed that ethanolic extract of senggani leaves have shown their antibacterial ability which is to inhibit the growth of the test bacteria E. coli (ATCC 8739), Sh. dysenteriae (UnasCC 310), $S$. aureus (ATCC 6539), and $P$. aeruginosa (ATCC 9027). This is supported by the ability of the antibacterial activitis of eight active substances that have been successfully screened.

\section{CONCLUSIONS}

Senggani leaves ethanolic extract contain eight active substances, including alkaloids, saponins, tannins, phenolics, flavonoids, triterpenoids, steroids, and glycosides. These active substances have the inhibition ability against the growth of all the tested bacteria.

The best ability of senggani leaves ethanolic extract in inhibiting $E$. coli bacteria was at a concentration of $100 \%$, Sh. dysenteriae and $P$. aeruginosa starting at the concentration of $75 \%$, and $S$. aureus starting at the concentration of $50 \%$.

\section{REFERENCES}

Akiyama H, Fujii K, Yamasaki O, Oono T, Iwatsuki K. 2001. Antibacterial action of several tannins against Staphylococcus aureus. Journal of Antimicrobial Chemotherapy. 48(4): 487-491. https://doi.org/10.1 093/jac/48.4.487

Alhanout K, Malesinki S, Vidal N, Peyrot V, Rolain JM, Brunel JM. 2010. New insights into the antibacterial mechanism of action of squalamine. Journal of Antimicrobial Chemotherapy. 65(8): 1688-1693. https://doi.org/10.1093/jac/dkq213

Angeh JE, Huang X, Sattler I, Swan GE, Dahse H, Hartl A, Eloff JN. 2007. Antimicrobial and anti- inflammatory activity of four known and one new triterpenoid from Combretum imberbe (Combretaceae). Journal of Ethnopharmacology. 110(1): 56-60. https://doi.org/10.1016/j.jep.2006.09 .002

Arabski M, Węgierek-Ciuk A, Czerwonka G, Lankoff A, Kaca W. 2012. Effects of saponins against clinical E. coli strains and Eukaryotic cell line. Journal of Biomedicine and Biotechnology. 2012: 1-6. https:// doi.org/10.1155/2012/286216

Apridamayanti P, Kurniawan H. 2018. Potensi senyawa antioksidan tanaman endemik pada Masyarakat Dayak Sekajang di Kalimantan Barat. Jurnal Pendidikan Informatika dan Sains. 7(1): 78-90.

Bachtiar SY, Tjahjaningsih W, Sianita N. 2012. Pengaruh ekstrak alga cokelat (Sargassum sp.) terhadap pertumbuhan bakteri Escherichia coli. Journal of Marine and Coastal Science. 1(1): 53-60.

Borges A, Abreu AC, Dias C, Saavedra MJ, Borges F, Simoes M. 2016. New perspectives on the use of phytochemicals as an emergent strategy to control bacterial infections including biofilms. Molecules. 21(7)877: 1-41. https://doi.org/10.3390/molecules2 1070877

Bouarab-Chibane L, Forquet V, Lanteri P, Clement Y, Leonard-Akkari L, Oulahal N, Bordes C. 2019. Antibacterial properties of polyphenols: characterization and QSAR (Quantitative StructureActivity Relationship) models. Frontiers in Microbiology. 10(829): 1-23. https://doi.org/10.338 9/fmicb.2019.00829

CLSI. 2016. Performance Standards for Antimicrobial Susceptibility Testing. 26th ed. Wayne (US): Clinical and Laboratory Standards Institute.

Cushnie TT, Lamb AJ. 2011. Recent advances in understanding the antibacterial properties of flavonoids. International Journal of Antimicrobial Agents. 38(2): 99-107. https://doi.org/10.1016/j.ijan timicag.2011.02.014

Danladi S, Wan-Azemin A, Sani YN, Mohd KS, US MR, Mansor SM, Dharmaraj S. 2015. Phytochemical screening, total phenolic and total flavonoid content, and antioxidant activity of different parts of Melastoma malabathricum. Jurnal Teknologi. 77(2): 63-8. https://doi.org/10.11113/jt.v77.5988

de Leon L, Lopez MR, Moujir L. 2010. Antibacterial properties of zeylasterone, a triterpenoid isolated from Maytenus blepharodes, against Staphylococcus aureus. Microbiology Research. 165(8): 617-626. https://doi.org/10.1016/j.micres.2 009.12.004

Dhuha S. 2016. Aktivitas antibakteri ekstrak etanol daun lamun (Syiringodium isoetifolium) terhadap 
bakteri Pseudomonas aeruginosa. Pharmacon. 5(1): 231-237.

Fahriya PS, Shofi MS. 2011. Ekstraksi Zat Aktif Antimikroba dari Tanaman Yodium (Jatropha multifida Linn) sebagai Bahan Baku Alternatif Antibiotik Alami. [Technical Report]. Semarang (ID): Universitas Diponegoro. eprints.undip.ac.id. ID Code 36753.

Harborne JB. 1987. Metode Fitokimia, Penuntun Cara Modern Menganalisis Tumbuhan. Terjemahan: Padmawinata K, Sudiro I. Bandung (ID): Institut Teknologi Bandung.

Jalius J, Muswita M. 2013. eksplorasi pengetahuan lokal tentang tumbuhan obat di Suku Batin, Jambi. Biospecies. 6(1): 28-35.

Joffry SM, Yob NJ, Rofiee MS, Affandi MMR, Suhaili Z, Othman F, Zakaria ZA. 2012. Melastoma malabathricum (L.) smith ethnomedicinal uses, chemical constituents, and pharmacological properties: a review. Evidence-Based Complementary and Alternative Medicine. 2012: 1-48. https://doi.org/10.1155/2012/258434

Karou D, Savadogo A, Canini A, Yameogo S, Montesano C, Simpore J, Traore AS. 2005. Antibacterial activity of alkaloids from Sida acuta. African Journal of Biotechnology. 4(12): 1452-1457.

Kurhekar JV. 2016. Tannins-antimicrobial chemical components. International Journal of Technology and Science. 9(3): 5-9.

Maesyaroh D, Imansyah EB, Nafratilova HF. 2017. Uji aktivitas antibakteri ekstrak etanol biji ganitri (Elaeocarpus sphaericus Schum.) terhadap pertumbuhan bakteri penyebab demam typhoid secara in vitro. BIO SITE Biologi dan Sains Terapan. 3(2): 65-70. https://doi.org/10.22437/bs.v 3i2.3095

Miklasińska-Majdanik M, Kępa M, Wojtyczka RD, Idzik D, Wąsik TJ. 2018. Phenolic compounds diminish antibiotic resistance of Staphylococcus aureus clinical strains. International Journal of Environmental Research And Public Health. 15(10)2321: 1-18. https://doi.org/10.3390/ijerph151 02321

Ncube NS, Afolayan AJ, Okoh Al. 2008. Assessment techniques of antimicrobial properties of natural compounds of plant origin: current methods and future trends. African journal of biotechnology. 7(12): 1797-1806. https://doi.org/10.5897/AJB07.6 13

Ngajow M, Abidjulu J, Kamu VS. 2013. Pengaruh antibakteri ekstrak kulit batang matoa (Pometia pinnata) terhadap bakteri Staphylococcus aureus secara in vitro. Jurnal Mipa. 2: 128-32. https://doi .org/10.35799/jm.2.2.2013.3121
Noviyanty Y, Linda AM. 2020. Profil fitokimia senyawa metabolit sekunder ekstrak etanol bunga senduduk (Melastoma malabathricum L). Journal of Pharmaceutical and Sciences, 3(1): 1-6. https:// doi.org/10.36490/journal-jps.com.v3i1.34

Nuria MC, Faizatun A, Sumantri. 2009. Uji aktivitas antibakteri ekstrak etanol daun jarak pagar (Jatropha curcas L) terhadap bakteri Staphylococcus aureus ATCC 25923, Escherichia coli ATCC 25922, dan Salmonella typhi ATCC 1408. Mediagro. 5(2): 26-27.

Nzogong RT, Ndjateu FSTN, Ekom SE, Fosso JM, Awouafack MD, Tene M, Tane $\mathrm{P}$, Morita $\mathrm{H}$, Choudhary MI, Tamokou JD. 2018. Antimicrobial and antioxidant activities of triterpenoid and phenolic derivatives from two Cameroonian Melastomataceae plants: Dissotis senegambiensis and Amphiblemma monticola. BMC Complementary and Alternative Medicine. 18(1)159: 1-11. https://doi.org/10.1186/s1290601 8-2229-2

Rahmatullah M, Mukti IJ, Haque AKMF, Mollik MAH, Parvin K, Jahan R, Rahman T. 2009. An ethnobotanical survey and pharmacological evaluation of medicinal plants used by the Garo Tribal Community living in Netrakona district, Bangladesh. Advances in Natural and Applied Sciences. 3(3) : 402-418.

Rao KN, Venkatachalam SR. 2000. Inhibition of dihydrofolate reductase and cell growth activity by the phenanthroindolizidine alkaloids pergularinine and tylophorinidine: the in vitro cytotoxicity of these plant alkaloids and their potential as antimicrobial and anticancer agents. Toxicology in Vitro. 14(1): 53-59. https://doi.org/10.1016/S0887-2333(99)000 92-2

Ringmichon CL, Shimpi SN, Gopalkrishnan B. 2010. Ethnomedicinal investigation on Melastoma malabathricum Linn. from Manipur. Journal of Herbal Medicine and Toxicology. 4(2): 141-144.

Roosita K, Kusharto CM, Sekiyama M, Fachrurozi Y, Ohtsuka R. 2008. Medicinal plants used by the Villagers of a Sundanese Community in West Java, Indonesia. Journal of ethnopharmacology. 115(1): 72-81. https://doi.org/10.1016/j.jep.2007.09.010

Salmi C, Loncle C, Vidal N, Letourneux Y, Fantini J, Maresca M, Brunel JM. 2008. Squalamine: an appropriate strategy against the emergence of multidrug resistant gram-negative bacteria?. PLOS One. 3(7): e2765. https://doi.org/10.1371/journal.po ne. 0002765

Samad NA, Nur N, Nik S, Kamal M, Yahaya N, Bin MY. 2018. Ethnobotanical, phytochemical, and pharmacological aspects of Melastoma sp. Malaysian Journal of Medicine and Health Sciences. 14: 153-163. 
Sari NM, Kuspradini H, Amirta R, Kusuma IW. 2018, April. Antioxidant activity of an invasive plant, Melastoma malabathricum and Its potential as herbal tea product. In IOP Conference Series: Earth and Environmental Science (Vol. 144, No. 1, p. 012029). IOP Publishing. Samarinda, East Kalimantan. 9th November 2007. https://doi.org/10 $.1088 / 1755-1315 / 144 / 1 / 012029$

Sembiring EN, Elya B, Sauriasari R. 2018. Inhibitory effect on arginase and total phenolic content determination of extracts from different parts of Melastoma malabathricum L. Journal of Young Pharmacists. 10(2): S114-S117. https://doi.org/10 .5530/jyp.2018.2s.23

Siregar AF, Sabdono A, Pringgenies D. 2012. Potensi antibakteri ekstrak rumput laut terhadap bakteri penyakit kulit Pseudomonas aeruginosa, Staphylococcus epidermidis, dan Micrococcus luteus. Journal of Marine Research. 1: 152-60

Setyowati, F. M. 2006. Pengetahuan Masyarakat Talang Mamak tentang pemanfaatan tumbuhan obat di Taman Nasional Bukit Tigapuluh. Jurnal Bahan Alam Indonesia. 5(1): 1-5.

Silalahi M, Supriatna J, Walujo EB. 2015. Local knowledge of medicinal plants in Sub-Ethnic Batak Simalungun of North Sumatra, Indonesia. Biodiversitas Journal of Biological Diversity. 16(1): 44-54. https://doi.org/10.13057/biodiv/d160106

Silalahi M, Khairiah A, Nisyawati N. 2020. Ethnomedicinal plants and practices related to pregnancy, childbirth, and postpartum healthcare of Minangkabau ethnic group, West Sumatra, Indonesia. Biodiversitas Journal of Biological Diversity. 21(10): 4597-4605. https://doi.org/10.13 057/biodiv/d211018

Soulef K, Abdelouahab Y, Dalal B. 2014. Effect of glycosides extract of the medicinal plant Glycyrrhiza glabra L. from the Region of Mlilli (Southeast of Algeria) on the growth of some human pathogenic bacteria. Journal of Scientific \& Innovative Research. 3(1): 28-34.

Sunawan S, Kurnia T, Asari H. 2018. Pengaruh ekstrak etanol biji ganitri (Elaecarpus sphaericus Schum.) terhadap pertumbuhan bakteri penyebab Disentri Basiler secara In Vitro. Jurnal Biosense. 1: 15-23.

Susanti D, Sirat HM, Ahmad F, Ali RM, Aimi N, Kitajima M. 2007. Antioxidant and cytotoxic flavonoids from the flowers of Melastoma malabathricum L. Food
Chemistry. 103(3): 710-716. https://doi.org/10.101 6/j.foodchem.2006.09.011

Sulistiyowati Y, Siswati AS. 2016. Uji potensi antibakteri sodium ascorbyl phosphate terhadap propionibacterium acnes in vitro. Mutiara Medika Jurnal Kedokteran dan Kesehatan. 11: 8-13.

Supriatno S, Rini AA. 2018. Uji fitokimia dan antibakteri ekstrak etanol buah kawista (Limonia acidissima L.) pada bakteri Escherichia coli. Prosiding Seminar Nasional Pendidikan Biologi. Mataram, Lombok, 8 Juni 2018.

Taha $\mathrm{H}$, Awang-Jamil Z, Aminuddin MF, Basri AM, Zaidi BQ, Ahmad N. 2021. Phytochemicals and antimicrobial analysis of selected medicinal plants from Brunei Darussalam. Biodiversitas Journal of Biological Diversity. 22(2): 601-606. https://doi.org /10.13057/biodiv/d220211

Takó M, Kerekes EB, Zambrano C, Kotogán A, Papp T, Krisch J, \& Vágvölgyi C. 2020. Plant phenolics and phenolic-enriched extracts as antimicrobial agents against food-contaminating microorganisms. Antioxidants. 9(2)165: 1-21. https://doi.org/10.3390/antiox9020165

Tangjitman K, Wongsawad C, Kamwong K, Sukkho T, Trisonthi C. 2015. Ethnomedicinal plants used for digestive system disorders by the Karen of Northern Thailand. Journal of Ethnobiology and Ethnomedicine. 11(1): 1-13. https://doi.org/10.1186 /s13002-015-0011-9

Wang XX, Zan K, Shi SP, Zeng KW, Jiang Y, Guan Y, Xiao CL, Gao HY, Wu LJ, Tu PF. 2013. Quinolone alkaloids with antibacterial and cytotoxic activities from the fruits of Evodia rutaecarpa. Fitoterapia. 89: 1-7. https://doi.org/10.1016/j.fitote.2013.04.007

Xie Y, Yang W, Tang F, Chen X, Ren L. 2015. Antibacterial activities of flavonoids: structureactivity relationship and mechanism. current medicinal chemistry. 22(1):132-149. https://doi.org/ 10.2174/0929867321666140916113443

Zakaria ZA, Raden Mohd, Nor RNS, Hanan Kumar G, Abdul Ghani ZDF, Sulaiman MR, Rathna Devi G, Fatimah CA. 2006. Antinociceptive, antiinflammatory and antipyretic properties of melastoma malabathricum leaves aqueous extract in experimental animals. Canadian Journal of Physiology and Pharmacology. 84(12): 1291-1299. https://doi.org/10.1139/y06-083 